\title{
Continental Migration Trends: Its Implications from an African Perspective
}

\author{
Daniel N Mlambo \\ University of Zululand, KwaDlangezwa, South Africa \\ mlambo1@ymail.com
}

\begin{abstract}
Migration is witnessed throughout the world, this is even true for a third world continent such as Africa, where individuals tend to move from one place to another propelled by diverse push and pull factors. This paper brings forward the degree of migration movements in Africa. Additionally, it seeks to understand the impact(s) of migration within the continent. It argues that migration in Africa is not a new phenomenon as it has been witnessed since colonialism often as a result of forced migration. However, post the colonial era, Africa has observed an upsurge of migration movements both documented and undocumented. This is manifested by the fact that Africa has remained an underdeveloped continent coupled with vast economic hindrances including unemployment, political instability, low growth rates, terrorism and corruption. In this vein, individuals move from place to place for better economic opportunities for themselves particularly to Western, Eastern and Southern African countries such as Nigeria, Ghana, Botswana, South Africa, Ivory Coast, Angola, Rwanda and Namibia. The paper concludes by outlining that if Africa is to limit and manage the evergrowing migration movements, then African heads of states should possibly improve their border patrol security, enhance rural agriculture and improve rural service delivery programmes. Moreover, to implement robust, well monitored and managed policies that intend to support and complement the policies of the African Union (AU), regional bodies and the Sustainable Development Goals (SDG's) with regards to African migration.
\end{abstract}

Keywords: Migration, Africa, development, push, pull

\section{Introduction}

Human migration is witnessed globally, this has been the case for centuries and mainly driven by various factors which include among other things lack of basic education opportunities, poverty and famine just to name a few. Internationally in 2017, there were an estimated 258 million migrants both in developed and developing countries (United Nations, 2017). By narrowing this to Africa, migration is not a recent development, individuals here have moved from place to place as a means of searching for better livelihood opportunities even before Europeans segregated and had their footprints within the continent through colonialism. In this sense, and particularly from the 1990s, Africa has often been referred to as the continent on the move, largely due to the enormous numbers in migration movement's (legal, illegal, and asylum, seekers) taking place from this time to date (De Haas, \& Flahaux, 2016). During colonialism, migration existed, however, here, forced migration was predominance through slavery practices (Falola, \& Usman, 2009). In this time, individuals were displaced to as far as Europe and other African countries, therefore, migration was prominent as a result of labour migration to industrial and mining areas, construction work and farms driven as a result of cheap labour practices (Bilger, \& Kraler, 2005). However, as Shimeles (2010) argues, while colonialism played a significant role in current African underdevelopment, to this day, most African states have retained close relationships with their erstwhile colonizers. If not migrating within Africa, individuals from Francophone states find it easier to travel to Belgium or France ${ }^{1}$ while those from Anglophone states tend to travel to English speaking countries.

Nonetheless, in Africa, most migration movements have and still take place within the continent. The continent is mainly manifested by two types of migration internal and external ${ }^{2}$. As a result, Africa witnesses both voluntarily and involuntarily migration patterns, which includes the migration movements of refugees ${ }^{3}$, undocumented migrants, nomads, seasonal and labour migrants (Adepoju, 2004). Diverse drivers and

\footnotetext{
${ }^{1}$ Nevertheless, this kind of international migration is predominantly taken by more affluent individuals, those who know or have close ties with other individuals in these countries and in some cases students who are pursuing their tertiary studies abroad.

${ }^{2}$ Internal migration is movement within the same geographical location (i.e. movement within ones country which may include rural to rural, rural to urban, urban to rural and urban to urban), while external migration is movement across ones country's borders i.e. moving from Mozambique to South Africa (Ellis, 2007; Singh, \& Khan, 2017).

${ }^{3}$ Globally in 2017, Africa at 0.50 percent, had the highest number of refugees and asylum seekers (United Nations, 2017).
} 
prevalent circumstances such as low wages, poverty, economic crisis, food insecurity, unstable political structures, low Gross Domestic Products (GDP) and unemployment have gradually increased current migration movements in Africa post-colonialism. While migration often leads to brain drain ${ }^{4}$ and an exodus of skilled individuals, it is relatively hard to track migration trends in Africa as in most cases these are undocumented and informal. The following section aims to broadly define the term migration. The subsequent sections delve into the available scholarly literature pertaining to migration trends in Africa. This is done by unpacking the causes of migration, factors that make individuals move and what pulls them to other regions and/or countries. The last sections conclude on what has been observed pertaining to migration in Africa and also offers possible recommendations on how Africa can perhaps deal with the high rate of current continental migration moving forward.

Migration: What's in the Meaning? What do we mean and what does this term entail from a broader perspective? According to Muzumbukilwa (2007) migration as a terminology has been defined extensively (both continentally and internationally) from policymakers, government officials, political scientists, historians and geography scholars who in their view offer various types 5 and meanings of this term. Therefore, it tends to mean different things to different people. In general terms, migration is normally defined as the movement of individuals from one place to another either internally or internationally and is often driven by the motive to equip themselves with better economic opportunities (Kok, 1999). On the other hand, Guild (2009) asserts that migration refers to cross-border movements of individuals, while Lee (1970) in his definition describes migration as a change in residence or boundaries crossed. Rubenstein and Bacon (1990) in their view see migration as a change in one's location on a permanent basis. However, for the purpose of this paper, I will utilize Kok's definition of migration as it is widely used in literature pertaining to migration movements from a global perspective.

\section{Literature Review}

Migration drivers in Africa: An Overview: Migration has over the past few decades become a hotly contested issue not only in Africa but from a global standpoint and academic literature. This is attested to the fact that it brings with it immense and varied issues that include amongst others brain drain, brain gain, human rights, xenophobia and human trafficking just to name a few (Doyle, 2004). From an African viewpoint, migration can be understood from the framework of the historical and political evolution of African states (Adepoju, 1998). The continent since its freedom from respective European colonizers has witnessed an increase of intra-regional and intra-continental migration trends both internal and external with the former being the most observed accounting for 80 percent of migration movements (United Nations, 2017). However, when talking about African migration movements, men seem to be the first in mind, nonetheless, over the years there has been a high rise in women migration. In Africa from 1990 to 2017, there has been an upward trend from 39.6 percent to 44.5 percent in female migration movements ${ }^{6}$ (United Nations, 2017) often as a result to uplift their own economic advancements. According to the United Nations (2017) in Africa, from 2000 to 2017, there has been a 67 percent increase in migration (see figure 1) from 15 million to 25 million, most of these taken by individuals who fall within the working-age bracket of (20 to 64 years).

While migration movements are witnessed throughout the African continent, it is, however, more noticeable and predominant in Western, Eastern and Southern African ${ }^{7}$ countries including South Africa, Botswana, Ivory Coast, Nigeria, Rwanda, Ghana, Namibia and Angola just to name a few (Agadjanian, 2008; Mlambo, 2017; United Nations, 2017). These are often referred to as major countries of destination primarily because they are viewed as economic hubs in Africa and between them pull an influx of migrants from neighbouring

\footnotetext{
${ }^{4}$ This refers to the loss of skilled individuals from third world or developing countries to those that are more developed (Docquier, 2006).

${ }^{5}$ These include among others economic migration, political migration, clandestine migration, seasonal migration and selective migration.

${ }^{6}$ However, women in their quest to migrate tend to face higher risks in relation to human trafficking, rape and violence which often leads to sexual exploitation.

${ }^{7}$ Globally, Ivory Coast, the Democratic Republic of Congo (DRC) and South Africa feature amongst the top twenty countries or areas hosting the largest number of migrants (United Nations, 2017).
} 
countries ${ }^{8}$ due to their relatively robust economies and level of infrastructural development (Mlambo, 2017). In this vein, and while some of these have been mentioned elsewhere in this paper, one cannot talk about migration without mentioning the push and pull factors (see table 1) that ultimately drive people to migrate with the view of seeking greener pastures elsewhere.

\section{Figure 1: Number of international migrants by region of destination, 2000-2017 (millions)}

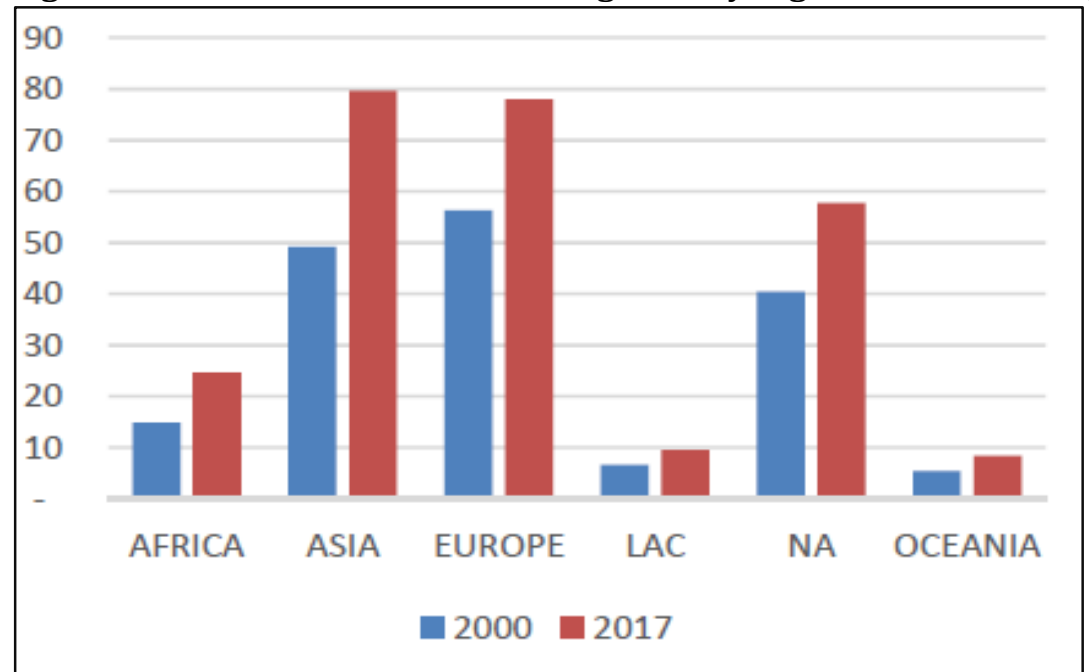

Note: NA refers to Northern America, while LAC refers to Latin America and the Caribbean.

Source: See United Nations (2017).

Table 1: Showing push and pull factors of migration

\begin{tabular}{ll}
\hline Push Factors & Pull Factors \\
\hline Lack of employment opportunities & Better employment opportunities \\
Conflicts & Stable security \\
Terrorism & Low levels of crime \\
High levels of crime & Better governance structures \\
Poor governance structures & Better health care system \\
Poor health care system & Better education system \\
Poor education system & Opportunities for youths \\
Lack of opportunities for youths & Better quality of life \\
Lack of service delivery & Better service delivery \\
Economic instability & Economic stability \\
\hline
\end{tabular}

Source: Digbyet al. (2001).

As a result, Brown (2015) asserts that these aforementioned factors contribute substantially to making people want to move elsewhere often contributing to the surge in legal and illegal migration movements. However, Mlambo (2017) in his analysis, opines that migration is a two-fold phenomenon, to him, whether legal or not, it may bring with it vast benefits for both countries (sender and receiver). Moving forward and from his view, a migrant may bring with him/her needed skills otherwise not available in the country of destination. Hence, migrants may as a result of employment send capital to their country of origin, hence, contributing to continental financial flows. Nevertheless, it is negative in the sense that a country may lose people with needed skills and as a result of this, another country may acquire these individuals with these skills for their own development and economic growth. As a result of this, some countries rely on skilled migrants as a means to improve the scarcity of skilled labour (United Nations, 2017). Karaguezian \& VerdierChouchane (2014) emphasize that migration may also be a burden not only for the migrant but in most cases also for the receiving country. This is because the migrant may want to sustain himself/herself in that

${ }^{8}$ These include but not limited to those from Benin, Togo, Niger, Chad, Cameroon, Guinea, Mali, Mauritania, Lesotho, Burundi, Gabon, Mozambique and Zimbabwe. 
particular country and may go as far as searching for employment in the informal sector and as a result further contributing in the expansion of these informal sectors in that specific country. With that said, Njuguna (2016) offers the sentiments that migration has undoubtedly contributed in slowing the pace of African development, contributed to further rising unemployment levels, congestion and rapid rise in urbanization mostly as a result of rural to urban migration.

With the view of tackling this ever-rising African migration trend, the establishment of continental migration frameworks from the African Union (AU) such as the migration policy framework together with the African common position on migration and development shows the seriousness and determination to limit the rate of migration movements (Abebe, 2017). This is further attested to the migration related targets that were included in the Sustainable Development Goals (SDG's). Of importance here, is target 10.7, which outlines the need for all countries to simplify systematic, safe and accountable migration of individuals through robust and well-managed migration policies (United Nations, 2017).

\section{Methodology}

This paper adopts a qualitative methodology by relying on secondary sources to collect required data on the topic under study. The researcher exploited relevant published works from books, journals, newspapers, published and unpublished articles such as dissertations and thesis together with credible and reliable online sources of applicable organizations dealing with and/or monitoring migration in Africa. These included the most recent, credible and reliable migration publications from the United Nations that provided the study with recent data on current global migration trends. The dependence on secondary sources enabled a robust and wider clarification of the topic under investigation. All data retrieved was subjected to comprehensive qualitative analysis through the use of content analysis. Content analysis is a systematic approach to qualitative data analysis that identifies and summarises message content. In essence, it makes use of acute reflection and analysis of primary and secondary data collection. It refers to the analysis of books, brochures, written documents, transcript, news reports, conference reports and visual media (Neuendorf, 2002). This method assisted in analysing and reacting to articles from diverse sources.

African migration: The Way Forward: Migration is a huge task to curb not only in Africa but globally. This is notwithstanding the fact that coming up with solid migration blueprints requires the extensive task of mobilizing various stakeholders, sponsors, government support and much-needed capital. A question that may then arise here is, how (if possible) can African states come up with a robust remedy to limit this high rate of migration phenomena. Nevertheless, I argue that perhaps the following measures should be introduced by African heads of states as instruments to perhaps limit and regulate the high levels of intracontinental migration movements. However, these policies should (if probable) correlate with those of other African countries, continental organizations and regional organizations in their fight against migration.

Improve border patrol services: As a result of diverse socio-economic structures in most African countries, not all states are migrant receivers, however, countries such as South Africa, Nigeria, Ghana, Ivory Coast Namibia and Botswana are. Hence, while border services are tasked with the observation and control of border movements, in most cases within the African context these are sometimes severely affected by corruption, unavailability of human resources, weak or unavailability of robust security structures and at times required technological services (Magidimisha et al., 2018). In this regard, African countries should implement vast resources to further strengthen their weak borders. This entails fighting border corruption from government officials, police, having sufficient security services at border gates and involving regional bodies such as the Southern African Development Community (SADC), Economic Community of West African States (ECOWAS), The East African Community (EAC) and others in smoothing as assisting in regional and continental migration movements. While these alone may not stop nor limit migration movements particularly those that are undocumented, it may however, play a pivotal role in the facilitation, tracking and managing of migration movements.

Increase support for rural agriculture: According to Chitonge (2015) in most geographical areas within Africa, agriculture plays a vital role in generating income for individuals as this in most cases is their source of income and livelihood. Thus, African heads of states should design and implement policies that ought to 
enhance and promote rural agriculture so individuals can through agricultural practices further sustain themselves and their families. This may in turn support small and emerging farmers and co-operatives that are involved in agricultural activities and may limit the rate of rural to urban migration in order to acquire better employment opportunities and income.

Improve rural service delivery: Lack of basic service delivery is also of concern in many African states, this is shown by the huge service delivery protests in some African states. Hence, African countries should undoubtedly improve their rate of service delivery programmes especially to those individuals situated in rural settings. These services include but not limited to healthcare systems, basic infrastructure and education facilities. While some of these may create temporary or seasonal employment opportunities, they may however also assist in rural to urban migration.

\section{Conclusion and Recommendations}

This paper has explored the implications of continental migration from an African perspective. It has argued that migration in Africa is not a new occurrence and has been witnessed here since the colonial era through forced migration. However, in recent years, particularly post-colonialism, it has gradually become a complex phenomenon driven by diverse and varied components. This is particularly true for Africa as a result of its uneven development patterns, low GDP, unemployment, poverty, political instability and lack of economic opportunities. A significant amount of this migration takes place within the continent often driven by the desire to acquire better economic prospects especially to Western, Eastern and Southern African countries such as Ivory Coast, Nigeria, South Africa, Botswana and Rwanda. Thus, migration has forever been an increasing trend in Africa and often hard to track and maintain. While at times it is beneficial to other countries as a result of acquiring skilled individuals, it has however further slowed down the pace of African development, contributed to urbanization and congestion mostly driven by undocumented migrants. Africa is the least developed continent and with modern rates of high migration (mostly undocumented), this seems as if it will further impede on its development and economic growth endeavours moving forward.

This paper thus recommends that African leaders should perhaps try and improve their border patrol services, support rural agriculture and improve rural service delivery programmes. These initiatives could perhaps both in the short and long run (if properly implemented and monitored) limit migration movements. In this respect, those thinking of migrating could perhaps think differently as a result of (1) migration security at border gates would be tightened and strong (2) those based in rural areas would be generating income from agricultural activities, receiving government support and ultimately individuals would have access to much-needed services like basic education, clinics and needed infrastructure. The paper further recommends that African heads of states must implement more vigorous, well monitored and managed policies, these should (if possible) align or complement those of continental institutions such as the AU and African regional bodies such as the SADC, EAC, ECOWAS and others. The working together of African states, continental institutions and regional bodies may further support and complement the goals of the SDG's with regards to African migration moving forward.

\section{References}

Abebe, T. T. (2017). Migration Policy Frameworks in Africa. Retrieved from, https://issafrica.s3.amazonaws.com/site/uploads/ar2.pdfAccessed 6 April 2018

Adepoju, A. (1998). Linkages between internal and international migration: The African Situation. Retrieved from, https://onlinelibrary.wiley.com/doi/pdf/10.1111/1468-2451.00151 Accessed10 April 2018

Adepoju, A. (2004). Trends in International Migration in and from Africa in Massey, D. S. \& Taylor, J. D. (Eds). (2004). International Migration: Prospects and Policies in a Global Market. Oxford, Oxford University Press.

Agadjanian, V. (2008). Research on International Migration within Sub-Saharan Africa: Foci, Approaches and Challenges. The Sociological Quarterly, 49(3), 407-421.

Bilger, V. \& Kraler, A. (2005). Introduction: African Migrations: Historical Perceptions and Contemporary Dynamics. Retrieved from, https://stichproben.univie.ac.at/fileadmin/user_upload/p_stichproben /Artikel/Nummer08/03_Introduction.pdf Accessed 19 March 2018. 
Brown. E. (2015). Drivers of irregular migration in North Africa. Retrieved from, https://assets.publishing.service.gov.uk/media/57a08968ed915d622c0001df/HDQ12711.pdf Accessed 19 March 2018

Canagarajah, S. (2017). The Routledge Book of Migration and Language. New York, Routledge.

Chitonge, H. (2015). Economic Growth and Development in Africa: Understanding Trends and Prospects. New York, Routledge.

De Haas, H. \& Flahaux, M. L. (2016). African migration, trends, patterns, drivers. Comparative migration studies, 4(1), 1-25.

Digby, B., Ferretti, J., Flintoff, I., Owen, A. \& Ryan, C. (2001). Global Challenges. Oxford, Heinemann Educational Publishers.

Docquier, F. (2006). The Brain Retrieved from,https://www.researchgate.net/publication/228394436_The_brain_drainAccessed 1 April 2018

Doyle, M. W. (2004). The Challenge of World Wide Migration. Journal of International Affairs, 57(2), 1-5.

Ellis, A. F. (2007). Causes, Aftermaths of the Economic, Political and Cultural Migration in the Area of the Caribbean and Central America During the XXth Century. Paris, Publibook.

Falola, T. \& Usman, A. (2009). Movements, Borders and Identities in Africa. Rochester, University of Rochester Press.

Guild, E. (2009). Security and Migration in the $21^{\text {st }}$ Century. Cambridge, Polity Press.

Karaguezian, C. \& Verdier-Chouchane, A. (2014). Taking Africa's Irregular Migrants into Account: Trends, Challenges and Policy Options. African Development Bank, 5(1), 2-15

Kok, P. (1999). The definition of Migration and it Application: Making sense of recent South African cases and survey data. South African Journal of Demography, 7(1), 19-30.

Lee, E. S. (1970). A Theory of Migration in Demko G. J, Ross, H. M. \& Schrell, G. A. (1970). (Eds). An Introduction to Population. Archives Books, New Delhi.

Magidimisha, H. H., Khalema, N. E., Chipungu, L., Chirimambowa, T. C. \& Chimdza, T. L. (2018). Crisis, Identity and Migration in Post-Colonial Southern Africa. Springer International Publishing, Switzerland.

Mlambo, V. H. (2017). Cross-border Migration in the Southern African Development Community: Benefits, Problems and Future Prospects. Journal of Social and Development Science, 8(4), 42-56.

Muzumbukilwa, W. (2007). The Impact of Government Migration Policies on Foreigners known as AMAKWEREKWERE in South Africa. Masters Dissertation. University of KwaZulu-Natal. South Africa.

Neuendorf, K. A. (2002). The Content Analysis Handbook, $1^{\text {st }}$ Edition. United States of America, Sage Publications.

Njuguna, E. (2016). Government Measure Aimed at Curbing Rural-Urban Migration in Africa. Retrieved from, https://soapboxie.com/world-politics/GOVERNMENT-MEASURES-AIMED-AT-CURBING-RURAL-TOURBAN-MIGRATIONAccessed 7 March 2018

Rubenstein, J. M. \& Bacon, R. S. (1990). The Cultural Landscape. An Introduction to Human Geography. Prentice Hall of India, New Delhi.

Shimeles, A. (2010). Migration Patterns, Trends in Policy Issues in Africa. Retrieved from, https://www.afdb.org/fileadmin/uploads/afdb/Documents/Procurement/Project-relatedProcurement/WORKING\%20119\%20word\%20document\%20AA.PDFAccessed 26 March 2018

Singh, S. B. \& Khan, S. (2017). Migration Dynamics in Western and Southern Africa. Nordic Journal of African Studies, 26(2), 79-87.

Sinha, B. R. K. (2005). Human Migration Concepts and Approaches. Retrieved from, http://www.mtafki.hu/konyvtar/kiadv/FE2005/FE20053-4_403-414.pdfAccessed 10 April 2018

Talani, L. S. \& MacMahon, S. (2015). Handbook of the International Political Economy of Migration. Cheltenham, Edward Elgar Publishing.

United Nations, Department of Economic and Social Affairs, Population Division. (2017). International Migration Report 2017. http://www.un.org/en/development/desa/population /migration/publications/migrationreport/docs/MigrationReport2017.pdfAccessed 22 May 2018.

United Nations, Department of Economics and Social Affairs, Population Division. (2017). Trends in $\begin{array}{lllll}\text { International } & \text { Migration } & \text { Stock: } & \text { The } & 2017\end{array}$ http://www.un.org/en/development/desa/population/migration/publications/populationfacts/doc s/MigrationPopFacts20175.pdfAccessed 21 May 2018. 